\title{
Protection of olive planting stocks against parasitism of root-knot nematodes by arbuscular mycorrhizal fungi
}

\author{
P. Castillo ${ }^{a *}$, A. I. Nico ${ }^{a}$, C. Azcón-Aguilar ${ }^{b}$, C. Del Río Rincón ${ }^{c}$, C. Calvet ${ }^{d}$, and \\ R. M. Jiménez-Díaz ${ }^{\mathrm{a}, \mathrm{e}}$ \\ a'nstituto de Agricultura Sostenible, Consejo Superior de Investigaciones Científicas (IAS-CSIC), Apdo 4084, 14080-Córdoba; \\ ${ }^{\text {b} E s t a c i o ́ n ~ E x p e r i m e n t a l ~ d e l ~ Z a i d i ́ n, ~ C o n s e j o ~ S u p e r i o r ~ d e ~ I n v e s t i g a c i o n e s ~ C i e n t i ́ f i c a s ~(E E Z-C S I C), ~ c / P r o f e s o r ~ A l b a r e d a ~ 1, ~ 18008-G r a n a d a ; ~}$ \\ 'Instituto de Investigación y Formación Agroalimentaria y Pesquera, Consejería de Innovación Ciencia y Empresa (IFAPA-CICE), Junta de \\ Andalucía, Avda Menéndez Pidal s/n, 14080-Córdoba; and IInstitut de Recerca i Tecnología Agroalimentàries (IRTA), Ctra de Cabrils s/ \\ n, 08348 Cabrils, Barcelona; and ${ }^{\circledR}$ Escuela Técnica Superior de Ingenieros Agrónomos y Montes (ETSIAM), Universidad de Córdoba, \\ Apdo 3048, 14080 Córdoba, Spain
}

The effects were investigated, under controlled conditions, of single and joint inoculation of olive planting stocks cvs Arbequina and Picual with the arbuscular mycorrhizal fungi (AMF) Glomus intraradices, Glomus mosseae or Glomus viscosum, and the root-knot nematodes Meloidogyne incognita and Meloidogyne javanica, on plant performance and nematode infection. Establishment of the fungal symbiosis significantly increased growth of olive plants by $88.9 \%$ within a range of $11 \cdot 9-214.0 \%$, irrespective of olive cultivar, plant age and infection by M. incognita or M. javanica. In plants free from AMF, infection by Meloidogyne spp. significantly reduced the plant main stem diameter by $22 \cdot 8-38 \cdot 6 \%$, irrespective of cultivar and plant age. Establishment of AMF in olive plants significantly reduced severity of root galling by $6 \cdot 3-36 \cdot 8 \%$ as well as reproduction of both Meloidogyne spp. by $11 \cdot 8-35 \cdot 7 \%$, indicating a protective effect against parasitism by root-knot nematodes. Infection by the nematodes influenced root colonization by AMF, but the net effect depended on the AMF isolate-olive cultivar combination. It is concluded that prior inoculation of olive plants with AMF may contribute to improving the health status and vigour of cvs Arbequina and Picual planting stocks during nursery propagation.

Keywords: biological control, Glomus spp., Meloidogyne spp., nematode-mycorrhiza interaction, nematode reproduction, Olea europaea

\section{Introduction}

Olive (Olea europaea) is grown extensively in the Mediterranean Basin, the subtropical regions of Australia, southern Africa, and North and South America. However, about $90 \%$ of 8 million ha of olive grown worldwide are located in Mediterranean countries (FAO, 2004), of which more than 1.3 million ha are found in Andalusia, southern Spain (Barranco, 2004).

Much of the increase of olive acreage in Andalusia during the past decade was mediated by the use of self-rooted planting stocks for the establishment of new orchards (Caballero \& Del Río, 2004). Therefore factors influencing the health of olive planting stocks are of utmost importance for the olive industry in Spain. Infection by

\footnotetext{
*E-mail: ag1cascp@uco.es

Accepted 17 January 2006
}

plant-parasitic nematodes may impair growth of olive planting stocks. Plant-parasitic nematodes associated with olive planting stocks in olive nurseries and olive orchards include root-knot (Meloidogyne spp.) and root-lesion (Pratylenchus spp.) nematodes (Lamberti \& Baines, 1969; Nico et al., 2002). Root-knot nematodes damage many crops, mainly by reducing plant growth and crop yield, causing serious losses to numerous agricultural crops worldwide (Sasser \& Freckman, 1987). Meloidogyne arenaria, Meloidogyne incognita and Meloidogyne javanica have been reported to significantly reduce growth of olive planting stocks (Lamberti \& Baines, 1969; Sasanelli et al., 2002; Nico et al., 2003).

Current emphasis in low input-based agrotechnology for crop production systems has stimulated the study and management of microbial interactions in the rhizosphere (Barea et al., 2002). In the particular case of modern olive production in the Mediterranean Basin, emerging technologies include the use of inoculants of arbuscular 
mycorrhizal fungi (AMF) as bioprotectors, phytostimulators or biofertilizers during the nursery production of quality olive planting stocks, among other approaches (Calvente et al., 2004). These fungi establish an obligate mutualistic symbiosis with many plant species that is considered beneficial to the plant because of the increased uptake of phosphorus and other scarcely mobile nutrients by mycorrhizal plants; other benefits include the improved resistance to biotic (Azcón-Aguilar \& Barea, 1996) and abiotic stresses (Ruiz-Lozano, 2003) that AMF confer to plants.

Most studies on the interactions between AMF and plant parasitic nematodes reported that root colonization by AMF increases tolerance of the host plant to Meloidogyne species, such as that of tomato and white clover to Meloidogyne hapla (Cooper \& Grandison, 1986); peanut to M. arenaria (Carling et al., 1996); banana to M. incognita (Jaizme-Vega et al., 1997); and Prunus rootstocks to M. javanica (Calvet et al., 2001). In contrast, a few studies reported that AMF failed to protect host plants against deleterious effects caused by root-knot nematodes, for example M. hapla on onion (MacGuidwin et al., 1985); M. incognita on soybean (Carling et al., 1989); and M. arenaria on grape (Atilano et al., 1981).

Olive trees grown under natural conditions are highly mycotrophic, as the establishment of mycorrhizal associations favours their development (Roldán-Fajardo \& Barea, 1985). Therefore it is likely that early mycorrhizal establishment in olive plants by inoculation of planting stocks during nursery propagation will be beneficial. Inoculation of olive planting stocks with AMF revealed significant increases in plant growth, precocity, production and tolerance to salinity (Roldán-Fajardo \& Barea, 1985; Rinaldelli \& Mancuso, 1996; Calvente et al., 2004), even in long-term field experiments (Estaún et al., 2003). However, there was no information available about the role of AMF in protecting olive plants against root-knot nematodes. The objectives of this research were: (i) to determine the protective effect of AMF on growth of olive planting stocks inoculated with Meloidogyne spp.; and (ii) to determine whether severity of root galling caused by Meloidogyne spp. as well as nematode reproduction in olive can be reduced by AMF colonization.

\section{Materials and methods}

\section{Nematode isolates}

Two isolates of root-knot nematodes, $M$. incognita race 1 and M. javanica, were used in this study. These isolates were obtained from olive planting stocks collected in commercial nurseries at Córdoba and Seville provinces (Andalusia) (Nico et al., 2003). To establish and maintain cultures of Meloidogyne spp., nematode isolates were increased on tomato plants (Lycopersicon esculentum cv. Roma) starting from a single egg mass (Nico et al., 2003). Inocula for experiments were obtained by extracting eggs and second-stage juveniles $\left(J_{2}\right)$ from 2-month-old cultures using 1\% sodium hypochlorite (Hussey \& Barker, 1973) followed by centrifugal flotation (Coolen, 1979).

\section{AMF isolates}

Two experiments were carried out. Isolates of three AMF were used for experiment I: Glomus mosseae, G. intraradices and G. viscosum. These isolates are registered in the International Bank of Glomeromycota as BEG 119, BEG 123 and BEG 126, respectively. Glomus intraradices and G. viscosum were isolated from rhizosphere soil sampled from long-term established olive orchards (Calvente $e t$ al., 2004). Inocula were produced in the greenhouses at the Estación Experimental del Zaidín (Granada) using clover (Trifolium repens) and leek (Allium porrum) as host plants, and a vermiculite/sepiolite mixture (1:1, vol : vol) as substrate. Inocula consisted of rhizospheric soil containing spores, hyphae and mycorrhizal root fragments. The concentration of AMF inocula was adjusted to provide $c .375$ AMF propagules per inoculated plant. The concentration of inocula was determined by a dilution-series technique (Sieverding, 1991) and further calculation of the most probable number of propagules of the mycorrhizal fungus.

A second experiment was designed to determine the effects of two different isolates of the AMF species (G. intraradices, BEG 72 and G. mosseae, BEG 116) studied previously on growth of olive cv. Arbequina of two ages during nursery propagation. AMF used in experiment II were grown on leek-host plants at the Institut de Recerca i Tecnología Agroalimentàries, Cabrils, Barcelona, under controlled conditions in the greenhouse using an autoclaved sandy soil as potting substrate. The rhizosphere soil from the potted leek plants was thoroughly mixed and used as inoculum for olive planting stocks. The final concentration of mycorrhizal propagules in the mixture was determined as before and consisted of $400 \pm 50$ spores of G. intraradices and 18 sporocarps of G. mosseae in $10 \mathrm{~g}$ soil.

\section{Plant material}

For experiment I, 4-month-old planting stocks of olive cvs Arbequina and Picual were self-propagated by rooting leafy stem cuttings under mist tunnels. This procedure facilitates the rapid production of homogeneous plants suitable for the experiments (Caballero \& Del Río, 2004). For experiment II, 4- and 7-month-old cv. Arbequina planting stocks, kindly provided by Agromillora Catalana S.A. (Barcelona, Spain), were used. These plants also were self-propagated by rooting leafy stem cuttings under mist conditions in plastic tunnels, and are representative of commercial planting stock used by olive growers in Spain. In experiment I, 1-month-old, own-rooted stem cuttings with incipient root growth were selected for uniformity and transplanted into an autoclaved $\left(121^{\circ} \mathrm{C}, 1 \mathrm{~h}\right.$, twice) soil mixture (sand/clay loam, $2: 1, \mathrm{v} / \mathrm{v}$ ) in $5 \cdot 72 \times 5.72-\mathrm{cm}$ jiffy peat pots (Novosel). At transplanting, plants were inoculated with $c .15 \mathrm{~g}$ of the corresponding AMF by placing the inoculum substrate below the incipient root system. Nonmycorrhizal controls received the same amount of sterile inoculum substrate, which was supplemented with an AMF-free filtrate $(<20 \mu \mathrm{m})$ from a mixture of the 
AMF inocula to provide plants with the microbial populations accompanying the mycorrhizal fungi. In experiment II, olive planting stocks were inoculated with $5 \mathrm{~g}$ per plant of the inocula mentioned above, according to the treatment. The inoculum substrate was placed below a plant root system when plants were transplanted to 400-mL plastic containers filled with a pasteurized potting mixture (sandy soil-quartz/sand-sphagnum peat, $1: 1$, v/v). Noninoculated plants served as controls. Control plants received $5 \mathrm{~g}$ of the mycorrhizal substratum free of AMF inocula. Mycorrhizal and nonmycorrhizal control plants were maintained in the greenhouse at $20-26^{\circ} \mathrm{C}$ for 3 months, after which other treatments in the experiments were imposed.

\section{Growing conditions}

After nematode inoculations, experiments I and II were conducted in a growth chamber adjusted to $25 \pm 1^{\circ} \mathrm{C}$, $60-90 \% \mathrm{RH}$, and a 14-h photoperiod of fluorescent light at $360 \pm 25 \mu \mathrm{E} \mathrm{m}^{-2} \mathrm{~s}^{-1}$. These environmental conditions are optimal for growth of olive planting stocks as well as for the development and reproduction of root-knot nematodes in olive roots (Nico et al., 2003).

Experiment I was performed to determine the influence of prior mycorrhizal establishment by different AMF on the growth of olive plants as well as on parasitism and reproduction of root-knot nematodes in the plant. For that purpose, 4-month-old mycorrhizal and nonmycorrhizal planting stocks of cvs Arbequina and Picual were transferred to $15-\mathrm{cm}$-diameter clay pots (one plant per pot) filled with $0.5 \mathrm{~L}$ of an autoclaved soil mixture (sand/clay loam, $2: 1, \mathrm{v} / \mathrm{v})$. Mycorrhizal and nonmycorrhizal plants were inoculated by adding the nematode inocula (15 000 eggs $+J_{2}$ of each nematode isolate), suspended in $10 \mathrm{~mL}$ sterile distilled water, directly onto the root ball of a plant at transplanting. Sterile distilled water $(10 \mathrm{~mL})$ alone was used in the control treatments. Potted plants were watered as needed and fertilized weekly with a Hoagland's modified solution (Hoagland \& Arnon, 1950): $\mathrm{PO}_{4} \mathrm{H}_{2} \mathrm{~K}$ concentration was diluted fourfold to avoid P-mediated inhibition of mycorrhizal colonization by $\mathrm{P}$, and $20 \mu \mathrm{g} \mathrm{mL}^{-1}$ of a commercial iron chelate (Sequestrene 138 Fe G 100, Ciba-Geigy) was added to prevent typical olive chlorosis. The experiment consisted of a factorial treatment design comprised of two olive cultivars, three Meloidogyne isolates and four AMF, making 12 inoculation treatments per cultivar (Tables 1 and 3). Each treatment was replicated 20 times in a completely randomized design, each replicate consisting of a single potted plant. The experiment was terminated 120 days after inoculation with the nematodes.

Experiment II aimed to determine whether or not the age of planting stock would have an effect on the influence of AMF on growth of olive cv. Arbequina, as well as on parasitism and reproduction of root-knot nematodes in mycorhizal and nonmycorrhizal plants. For that purpose, mycorrhizal and nonmycorrhizal 4- and 7-month-old cv. Arbequina planting stocks were inoculated with $M$. incognita race 1 and $M$. javanica at transplanting, and incubated as described for experiment I. The inoculation procedure was as described above for experiment I together with water-treated control plants. The experiment was a factorial design including: two ages for planting stocks, three Meloidogyne isolates and three AMF isolates, making nine inoculation treatments per cultivar (Tables 2 and 4). Treatments were replicated 20 times in a completely randomized design, each replicate consisting of a single potted plant. The experiment ended 120 days after inoculation with the nematodes.

\section{Assessment of variables and data analysis}

Plant growth, severity of root galling and nematode reproduction were determined at the end of experiments I and II. The effect of treatments on plant growth was assessed by shoot dry weight and root fresh weight, shoot height, main stem diameter, and number of nodes of individual plants in inoculated and control plants. The three latter parameters were measured both at the time of nematode inoculation and at the end of the experiments, and growth was referred to as net increase during the experiments. Before assessment of root weight, the root system of a plant was gently washed free of adhering soil and debris, and the severity of root galling was assessed on a 1-6 rating scale according to the number of root galls developed $(1=$ no galls; $2=1-10 ; 2=11-20 ; 3=21-40 ; 4=41-70$; $5=71-90 ; 6 \geq 91$ galls; Marull \& Pinochet, 1991). Root samples of 1 or $3 \mathrm{~g}$ per plant for experiments I and II, respectively, were cleared and stained using the procedure described by Phillips \& Hayman (1970) and modified by Koske \& Gemma (1989), and the extent of AMF colonization was assessed using the grid-line intersect method (Giovannetti \& Mosse, 1980).

The nematode population in soil and roots was also assessed for each replicated plant at the end of the experiments. Nematodes were extracted from $100-\mathrm{cm}^{3}$ samples of soil by centrifugal flotation (Coolen, 1979). Soil was washed thoroughly with tap water through a $710-\mu \mathrm{m}$ mesh sieve and the filtered water was collected in a beaker and thoroughly mixed with $4 \%$ kaolin $(\mathrm{v} / \mathrm{v})$. This mixture was centrifuged at $1100 \mathrm{~g}$ for $4 \mathrm{~min}$, then the supernatants were discarded, pellets were resuspended in $250 \mathrm{~mL}$ $\mathrm{MgSO}_{4}(\delta=1 \cdot 16)$ and the new suspensions were centrifuged at $1100 \mathrm{~g}$ for $3 \mathrm{~min}$. Supernatants were sieved through $5 \mu \mathrm{m}$ mesh, and nematodes collected on the sieve were washed with tap water, transferred to Petri dishes and counted under a stereomicroscope (Coolen, 1979). To assess nematode population density in roots, the complete root system of a plant was washed free of soil and cut into 1-2-cm segments, and nematodes were extracted from a 2 -g sample by maceration followed by centrifugation. Root tissues were homogenized in $250 \mathrm{~mL}$ of a $1 \%$ solution of $\mathrm{NaOCl}$ using a Waring blender at $1800 \mathrm{~g}$ for $1 \mathrm{~min}$, and homogenates were centrifuged and extracted as described above (Coolen, 1979). Population densities were used to calculate the reproduction index $\left(R_{\mathrm{f}}=\right.$ final population density divided by initial population density). 
Data on plant growth parameters, nematode galling and reproduction, as well as percentage of AMF colonization, were subjected to ANOvA. Before analysis, percentage data were normalized by transforming them to arcsines $(Y / 100)^{1 / 2}$, and those corresponding to nematode counts were transformed to $\log _{10}(X+1)$ (Gomez \& Gomez, 1984). ANOVAs were carried out using STATISTIX $8 \cdot 0(\mathrm{NH}$ Analytical Software, Roseville, MN, USA). Orthogonal single degree of freedom contrasts were computed to test the effects of selected experimental treatment combinations (Gomez \& Gomez, 1984).

\section{Results}

Sixty-eight and $82 \%$ of the root system of olive planting stocks cvs Arbequina and Picual were colonized by the AMF in experiments I and II, respectively. In nematodefree plants, root colonization by mycorrhizal fungi was not significantly influenced $(P=0.05)$ by fungal species, irrespective of the olive cultivar (Table 1 ) and age of cv. Arbequina plants (Table 2 ). Infection by nematodes significantly influenced $(P<0.05)$ root colonization of $\mathrm{cv}$. Arbequina plants by AMF (Tables 1 and 2), but did not influence mycorrhizal colonization of the root system in cv. Picual (Table 1). However, the pattern of that influence varied within the AMF species and isolate. Thus root colonization of the 4-month-old cv. Arbequina plants by G. intraradices BEG 123 and G. viscosum BEG 126 was significantly reduced (c. 10 and $12 \%$, respectively) by nematode infection in experiment I (Table 1), but the same infection significantly increased root colonization of 4- and 7-month-old cv. Arbequina plants by G. intraradices BEG 72 (c. 13 and 17\%, respectively) in experiment II (Table 2). Conversely, colonization by G. mosseae BEG 119 in experiment I or by G. mosseae BEG 116 in experiment II was not significantly influenced by nematode infection.

In experiment I, severity of root galling by M. incognita race 1 in 4-month-old plants of cvs Arbequina and Picual averaged 3.8 and $2 \cdot 9$, respectively, while galling of M. javanica-infected plants was 3.9 and $3 \cdot 2$. Similarly, galling by the nematodes in 4- and 7-month-old cv. Arbequina plants in experiment II reached an average of 3.4 and 2.7 for $M$. incognita race 1 , and 3.7 and 2.9 for M. javanica. The reproduction rate $\left(R_{\mathrm{f}}\right)$ of the nematode ranged from 0.9 to 1.7 in cvs Arbequina and Picual in the two experiments. In nonmycorrhizal olive plants, neither the olive cultivar, nor the age of cv. Arbequina plants, nor

Table 1 Reproduction of Meloidogyne spp. and mycorrhizal root colonization by Glomus spp., alone and in combination in olive cvs Arbequina and Picual planting stocks 7 months after inoculation with the arbuscular mycorrhizal fungi (AMF) and 4 months after inoculation with the nematode

\begin{tabular}{|c|c|c|c|c|c|c|c|}
\hline \multirow[b]{2}{*}{ Inoculation treatment } & \multirow{2}{*}{$\begin{array}{l}\text { Treatment } \\
\text { number }\end{array}$} & \multicolumn{3}{|c|}{ cv. Arbequina } & \multicolumn{3}{|l|}{ cv. Picual } \\
\hline & & $\operatorname{AMF}(\%)^{a}$ & $\mathrm{RGS}^{\mathrm{b}}$ & $R_{\mathrm{f}}^{\mathrm{c}}$ & AMF (\%) & RGS & $R_{\mathrm{f}}$ \\
\hline Noninoculated control & 0 & 0.0 & $1 \cdot 0$ & - & - & $1 \cdot 0$ & - \\
\hline M. incognita & 1 & $0 \cdot 0$ & $3 \cdot 8$ & $1 \cdot 6$ & - & $2 \cdot 9$ & $1 \cdot 4$ \\
\hline M. javanica & 2 & $0 \cdot 0$ & 3.9 & $1 \cdot 7$ & - & $3 \cdot 2$ & $1 \cdot 5$ \\
\hline G. intraradices (BEG 123) & 3 & $78 \cdot 2$ & $1 \cdot 0$ & - & $73 \cdot 2$ & $1 \cdot 0$ & - \\
\hline M. incognita + Gi (BEG 123) & 4 & $75 \cdot 1$ & $2 \cdot 4$ & $1 \cdot 2$ & $58 \cdot 7$ & $2 \cdot 3$ & $1 \cdot 0$ \\
\hline M. javanica + Gi (BEG 123) & 5 & $65 \cdot 0$ & $2 \cdot 9$ & 1.5 & $68 \cdot 4$ & $2 \cdot 8$ & $1 \cdot 2$ \\
\hline G. mosseae (BEG 119) & 6 & $81 \cdot 5$ & $1 \cdot 0$ & - & $62 \cdot 8$ & $1 \cdot 0$ & - \\
\hline M. incognita + Gm (BEG 119) & 7 & $69 \cdot 1$ & $2 \cdot 6$ & $1 \cdot 1$ & $61 \cdot 3$ & $2 \cdot 5$ & 0.9 \\
\hline M. javanica + Gm (BEG 119) & 8 & $56 \cdot 5$ & $2 \cdot 9$ & $1 \cdot 4$ & $58 \cdot 0$ & $3 \cdot 0$ & $1 \cdot 0$ \\
\hline G. viscosum (BEG 126) & 9 & $82 \cdot 8$ & $1 \cdot 0$ & - & $61 \cdot 3$ & $1 \cdot 0$ & - \\
\hline M. incognita + Gv (BEG 126) & 10 & $75 \cdot 3$ & $2 \cdot 6$ & $1 \cdot 1$ & $73 \cdot 3$ & $2 \cdot 5$ & 0.9 \\
\hline M. javanica + Gv (BEG 126) & 11 & $70 \cdot 5$ & $2 \cdot 8$ & $1 \cdot 3$ & $55 \cdot 1$ & $3 \cdot 0$ & $1 \cdot 1$ \\
\hline \multicolumn{8}{|l|}{ Contrasts $(P)^{d}$} \\
\hline 1 vs. 2 & & $-{ }^{e}$ & ns & ns & - & ns & ns \\
\hline 1 vs. $4,7,10$ & & - & $<0.001$ & $<0.001$ & - & $<0.001$ & $<0.001$ \\
\hline 2 vs. $5,8,11$ & & - & $<0.001$ & $<0.001$ & - & 0.004 & $<0.001$ \\
\hline 3 vs. 6 & & ns & - & - & ns & - & - \\
\hline 3 vs. 9 & & ns & - & - & ns & - & - \\
\hline 6 vs. 9 & & ns & - & - & ns & - & - \\
\hline 3 vs. 4,5 & & $<0.001$ & - & - & ns & - & - \\
\hline 6 vs. 7,8 & & ns & - & - & ns & - & - \\
\hline 9 vs. 10,11 & & 0.047 & - & - & $\mathrm{ns}$ & - & - \\
\hline
\end{tabular}

${ }^{a}$ Percentage of AMF colonization was assessed using the grid-line intersect method (Giovannetti \& Mosse, 1980).

${ }^{\mathrm{b}}$ Severity of root galling (RGS) was rated on a 1-6 scale: 1 = no galls; $2=1-10 ; 2=11-20 ; 3=21-40 ; 4=41-70 ; 5=71-90 ; 6 \geq 91$ galls.

${ }^{\mathrm{c}} R_{\mathrm{f}}$ (nematode reproduction rate) $=P_{\mathrm{f}}$ (final nematode population per plant) $/ P_{\mathrm{i}}$ (initial nematode inoculum per plant)

${ }^{d}$ Orthogonal single-degree of freedom contrast of treatments. Probability for the $t$ statistic of linear single-degree of freedom contrasts;

$\mathrm{ns}=$ nonsignificant $(P=0.05)$.

$e_{-}=$not tested. 
Table 2 Reproduction of Meloidogyne spp. and mycorrhizal root colonization by Glomus spp., alone and in combination in olive cv. Arbequina planting stocks 7 and 10 months after inoculation with AMF and 4 and 7 months after inoculation with 15000 eggs and $J_{2}$ s per plant

\begin{tabular}{|c|c|c|c|c|c|c|c|}
\hline \multirow[b]{2}{*}{ Inoculation treatment } & \multirow{2}{*}{$\begin{array}{l}\text { Treatment } \\
\text { number }\end{array}$} & \multicolumn{3}{|c|}{ cv. Arbequina 4-month-old } & \multicolumn{3}{|c|}{ cv. Arbequina 7-month-old } \\
\hline & & $\operatorname{AMF}(\%)^{\mathrm{a}}$ & $R_{G} S^{b}$ & $R_{\mathrm{f}}^{\mathrm{c}}$ & AMF (\%) & RGS & $R_{\mathrm{f}}$ \\
\hline Noninoculated control & 0 & 0.0 & $1 \cdot 0$ & - & - & $1 \cdot 0$ & - \\
\hline M. incognita & 1 & $0 \cdot 0$ & $3 \cdot 4$ & 1.5 & - & $2 \cdot 7$ & $1 \cdot 3$ \\
\hline M. javanica & 2 & $0 \cdot 0$ & $3 \cdot 7$ & $1 \cdot 7$ & - & 2.9 & $1 \cdot 4$ \\
\hline G. intraradices (BEG 72) & 3 & $83 \cdot 4$ & $1 \cdot 0$ & - & $79 \cdot 2$ & $1 \cdot 0$ & - \\
\hline M. incognita + Gi (BEG 72) & 4 & $94 \cdot 6$ & $2 \cdot 3$ & $1 \cdot 1$ & $94 \cdot 4$ & $2 \cdot 3$ & 0.9 \\
\hline M. javanica + Gi (BEG 72) & 5 & $93 \cdot 6$ & $2 \cdot 7$ & $1 \cdot 2$ & $91 \cdot 4$ & $2 \cdot 6$ & $1 \cdot 0$ \\
\hline G. mosseae (BEG 116) & 6 & $78 \cdot 0$ & $1 \cdot 0$ & - & $71 \cdot 2$ & $1 \cdot 0$ & - \\
\hline M. incognita + Gm (BEG 116) & 7 & $80 \cdot 0$ & $2 \cdot 4$ & $1 \cdot 2$ & $76 \cdot 2$ & $2 \cdot 3$ & $1 \cdot 0$ \\
\hline M. javanica + Gm (BEG 116) & 8 & $78 \cdot 2$ & $2 \cdot 7$ & $1 \cdot 3$ & $71 \cdot 8$ & $2 \cdot 6$ & $1 \cdot 0$ \\
\hline \multicolumn{8}{|l|}{ Contrasts $(P)^{d}$} \\
\hline 1 vs. 2 & & $-^{e}$ & ns & ns & - & ns & ns \\
\hline 1 vs. 4,7 & & - & $<0.001$ & $<0.001$ & - & 0.001 & $<0.001$ \\
\hline 2 vs. 5,8 & & - & $<0.001$ & $<0.001$ & - & 0.019 & $<0.001$ \\
\hline 3 vs. 6 & & $\mathrm{~ns}$ & - & - & ns & - & - \\
\hline 3 vs. 4,5 & & 0.004 & - & - & 0.042 & - & - \\
\hline 6 vs. 7,8 & & ns & - & - & ns & - & - \\
\hline
\end{tabular}

aPercentage of AMF colonization was assessed using the grid-line intersect method (Giovannetti \& Mosse, 1980).

bSeverity of root galling (RGS) was rated on a 1-6 scale: 1 = no galls; $2=1-10 ; 2=11-20 ; 3=21-40 ; 4=41-70 ; 5=71-90 ; 6 \geq 91$ galls.

${ }^{\mathrm{c}} R_{\mathrm{f}}$ (nematode reproduction rate) $=P_{\mathrm{f}}$ (final nematode population per plant) $/ P_{\mathrm{i}}$ (initial nematode inoculum per plant).

${ }^{\mathrm{d} O r t h o g o n a l}$ single-degree of freedom contrast of treatments. Probability for the $t$ statistic of linear single-degree of freedom contrasts;

ns $=$ nonsignificant $(P=0 \cdot 05)$.

$e_{-}=$not tested.

root-knot nematode species influenced $(P=0.05)$ the severity of root galling and nematode reproduction (Tables 1 and 2). However, both root galling and nematode reproduction were significantly reduced in mycorrhizal plants $(P<0.05)$ compared with those in nonmycorrhizal plants infected by nematodes, irrespective of the olive cultivar and age of cv. Arbequina plants (Tables 1 and 2).

Disease symptoms on above-ground plant parts were not observed on mycorrhizal and nonmycorrhizal olive plants infected by root-knot nematodes or on water-treated control plants, irrespective of olive cultivar and age of $\mathrm{cv}$. Arbequina plants. However, growth of both cultivars in experiment I determined by shoot DW and root FW, as well as relative growth (expressed as relative increase referred to the initial measure of the growth parameter determined at the time of nematode inoculation) of shoot height, main stem diameter and number of nodes, was significantly influenced $(P<0.05)$ by cultivar, inoculation treatment and cultivar $\times$ inoculation treatment interaction (Table 3). Similarly, growth of cv. Arbequina in experiment II was significantly influenced $(P<0.05)$ by plant age, inoculation treatment and their interaction (Table 4).

In nematode-free planting stocks, growth of 4-monthold plants of both cultivars (experiment I) and of 4- and 7-month-old plants of olive cv. Arbequina (experiment II) was significantly higher $(P<0.05)$ for mycorrhizal compared with nonmycorrhizal plants, as indicated by all growth parameters and both cultivars (Table 3 ) and age of cv. Arbequina plants (Table 4). In general, the infection by
Meloidogyne spp. did not influence growth of olive planting stocks in experiments I and II (Tables 3 and 4), except for a significant reduction $(P<0 \cdot 05)$ of the plant main stem diameter of nonmycorrhizal plants compared with that of nematode-free plants in cvs Arbequina and Picual (Table 3) and different ages of cv. Arbequina (Table 4). However, there were no statistically significant differences between nonmycorrhizal plants infected and uninfected by Meloidogyne for shoot DW and root FW, nor for the relative increase in shoot height and number of nodes, irrespective of cultivar (Table 3 ) and age of cv. Arbequina plants (Table 4).

In nematode-infected olive planting stocks, growth of 4-month-old plants of both cultivars (experiment I), and that of 4- and 7-month-old plants of cv. Arbequina (experiment II), was significantly higher $(P<0.05)$ for mycorrhizal than for nonmycorrhizal plants, as indicated by all growth parameters irrespective of cultivar and age (Tables 3 and 4). Exceptions to these results were shoot height in 4-month-old cv. Arbequina infected by either of the two Meloidogyne species; root FW and shoot height of cv. Picual plants infected by M. javanica (Table 3); root FW in 4- and 7-month-old olive cv. Arbequina; and number of nodes in cv. Picual plants infected by either Meloidogyne species (Tables 3 and 4).

\section{Discussion}

Establishment of AMF in plant root systems is considered a biological means of protection against plant diseases 
Table 3 Plant growth of olive planting stocks cvs Arbequina and Picual 7 months after inoculation with the arbuscular mycorrhizal fungi (Glomus spp.) and 4 months after inoculation with Meloidogyne spp.

\begin{tabular}{|c|c|c|c|c|c|c|c|c|c|c|c|}
\hline \multirow[b]{3}{*}{ Inoculation treatment ${ }^{\mathrm{a}}$} & \multirow[b]{3}{*}{$\begin{array}{l}\text { Treatment } \\
\text { number }\end{array}$} & \multicolumn{5}{|c|}{ cv. Arbequina } & \multicolumn{5}{|c|}{ cv. Picual } \\
\hline & & \multicolumn{5}{|c|}{ Growth increase $^{b}$} & \multicolumn{5}{|c|}{ Growth increase } \\
\hline & & $\begin{array}{l}\text { Shoot } \\
\text { DW (g) }\end{array}$ & $\begin{array}{l}\text { Root } \\
\text { FW (g) }\end{array}$ & $\begin{array}{l}\text { Shoot } \\
\text { height } \\
(\mathrm{cm})\end{array}$ & $\begin{array}{l}\text { Main stem } \\
\text { diameter } \\
(\mathrm{cm})\end{array}$ & $\begin{array}{l}\text { Number } \\
\text { of nodes }\end{array}$ & $\begin{array}{l}\text { Shoot } \\
\text { DW (g) }\end{array}$ & $\begin{array}{l}\text { Root } \\
\text { FW (g) }\end{array}$ & $\begin{array}{l}\text { Shoot } \\
\text { height } \\
(\mathrm{cm})\end{array}$ & $\begin{array}{l}\text { Main stem } \\
\text { diameter } \\
(\mathrm{cm})\end{array}$ & $\begin{array}{l}\text { Number } \\
\text { of nodes }\end{array}$ \\
\hline Noninoculated control & 0 & $3 \cdot 47$ & 3.56 & $24 \cdot 62$ & $1 \cdot 14$ & $13 \cdot 25$ & $3 \cdot 12$ & $3 \cdot 42$ & $19 \cdot 39$ & $0 \cdot 71$ & $12 \cdot 50$ \\
\hline M. incognita & 1 & $3 \cdot 01$ & $3 \cdot 48$ & $24 \cdot 01$ & $0 \cdot 72$ & $12 \cdot 70$ & $2 \cdot 94$ & $3 \cdot 35$ & $19 \cdot 25$ & $0 \cdot 45$ & $12 \cdot 65$ \\
\hline M. javanica & 2 & $3 \cdot 26$ & 3.55 & $24 \cdot 65$ & $0 \cdot 70$ & $13 \cdot 20$ & 3.08 & $3 \cdot 51$ & $20 \cdot 81$ & $0 \cdot 43$ & $12 \cdot 35$ \\
\hline G. intraradices (BEG 123) & 3 & 3.81 & 4.57 & $31 \cdot 62$ & 1.35 & $15 \cdot 75$ & $4 \cdot 40$ & $4 \cdot 34$ & $26 \cdot 42$ & 0.95 & $15 \cdot 20$ \\
\hline M. incognita + Gi (BEG 123) & 4 & 3.75 & $4 \cdot 02$ & $27 \cdot 63$ & $1 \cdot 22$ & $14 \cdot 50$ & $3 \cdot 70$ & $4 \cdot 04$ & $22 \cdot 22$ & $0 \cdot 85$ & $14 \cdot 45$ \\
\hline M. javanica + Gi (BEG 123) & 5 & 3.84 & 3.94 & $25 \cdot 53$ & $1 \cdot 15$ & $14 \cdot 35$ & $4 \cdot 42$ & 4.09 & $22 \cdot 50$ & $0 \cdot 79$ & 14.55 \\
\hline G. mosseae (BEG 119) & 6 & $4 \cdot 20$ & $4 \cdot 19$ & $32 \cdot 26$ & $1 \cdot 46$ & $15 \cdot 70$ & 3.54 & $4 \cdot 31$ & $24 \cdot 02$ & 0.97 & $16 \cdot 30$ \\
\hline M. incognita + Gm (BEG 119) & 7 & $4 \cdot 48$ & $4 \cdot 08$ & $30 \cdot 38$ & $1 \cdot 20$ & $14 \cdot 85$ & 3.33 & $4 \cdot 04$ & $22 \cdot 97$ & $0 \cdot 74$ & $13 \cdot 30$ \\
\hline M. javanica + Gm (BEG 119) & 8 & $4 \cdot 51$ & 3.95 & $30 \cdot 44$ & $1 \cdot 21$ & $15 \cdot 55$ & $3 \cdot 15$ & $3 \cdot 88$ & $21 \cdot 58$ & $0 \cdot 74$ & $13 \cdot 15$ \\
\hline G. viscosum (BEG 126) & 9 & $4 \cdot 45$ & 4.09 & 33.04 & $1 \cdot 42$ & $15 \cdot 70$ & $3 \cdot 41$ & $4 \cdot 23$ & 24.93 & 0.99 & $14 \cdot 60$ \\
\hline M. incognita + Gv (BEG 126) & 10 & 3.78 & $4 \cdot 01$ & $25 \cdot 79$ & $1 \cdot 11$ & $14 \cdot 70$ & 3.82 & $3 \cdot 82$ & $23 \cdot 22$ & $0 \cdot 66$ & $13 \cdot 25$ \\
\hline M. javanica + Gv (BEG 126) & 11 & 4.53 & $4 \cdot 03$ & $29 \cdot 29$ & $1 \cdot 10$ & $15 \cdot 20$ & $4 \cdot 10$ & 3.94 & $21 \cdot 70$ & $0 \cdot 86$ & $14 \cdot 35$ \\
\hline \multicolumn{12}{|l|}{ Contrasts $(P)^{\mathrm{c}}$} \\
\hline 0 vs. $3,6,9$ & & $0 \cdot 010$ & 0.001 & 0.001 & 0.009 & $<0.001$ & 0.009 & 0.001 & 0.001 & 0.033 & 0.001 \\
\hline 0 vs. 1,2 & & ns & ns & ns & $<0.001$ & ns & ns & ns & ns & 0.036 & ns \\
\hline 1 vs. $4,7,10$ & & $<0.001$ & 0.008 & ns & $<0.001$ & 0.003 & 0.008 & 0.018 & 0.042 & 0.015 & ns \\
\hline 2 vs. $5,8,11$ & & $<0.001$ & 0.043 & ns & $<0.001$ & 0.005 & 0.002 & ns & ns & 0.003 & ns \\
\hline
\end{tabular}

${ }^{a}$ Data are means of 20 replicated olive planting stocks per treatment combination. Plants were inoculated with 15000 eggs $+J_{2}\left(P_{i}\right)$ of Meloidogyne spp. ${ }^{b}$ Average growth of each parameter during the experiment.

${ }^{\circ}$ Orthogonal single-degree of freedom contrast of treatments. Probability for the $t$ statistic of linear single-degree of freedom contrasts; ns = not significant $(P>0.05)$.

Table 4 Plant growth of olive planting stock cv. Arbequina 7 months after inoculation with the arbuscular mycorrhizal fungi (Glomus spp.) and 4 or 7 months after inoculation with Meloidogyne spp.

\begin{tabular}{|c|c|c|c|c|c|c|c|c|c|c|c|}
\hline \multirow[b]{3}{*}{ Inoculation treatment ${ }^{\mathrm{a}}$} & \multirow[b]{3}{*}{$\begin{array}{l}\text { Treatment } \\
\text { number }\end{array}$} & \multicolumn{5}{|c|}{ cv. Arbequina 4-month-old } & \multicolumn{5}{|c|}{ cv. Arbequina 7-month-old } \\
\hline & & \multicolumn{5}{|c|}{ Growth increase $^{b}$} & \multicolumn{5}{|c|}{ Growth increase } \\
\hline & & $\begin{array}{l}\text { Shoot } \\
\text { DW (g) }\end{array}$ & $\begin{array}{l}\text { Root } \\
\text { FW (g) }\end{array}$ & $\begin{array}{l}\text { Shoot } \\
\text { height } \\
(\mathrm{cm})\end{array}$ & $\begin{array}{l}\text { Main stem } \\
\text { diameter } \\
(\mathrm{cm})\end{array}$ & $\begin{array}{l}\text { Number } \\
\text { of nodes }\end{array}$ & $\begin{array}{l}\text { Shoot } \\
\text { DW (g) }\end{array}$ & $\begin{array}{l}\text { Root } \\
\text { FW (g) }\end{array}$ & $\begin{array}{l}\text { Shoot } \\
\text { height } \\
(\mathrm{cm})\end{array}$ & $\begin{array}{l}\text { Main stem } \\
\text { diameter } \\
(\mathrm{cm})\end{array}$ & $\begin{array}{l}\text { Number } \\
\text { of nodes }\end{array}$ \\
\hline Noninoculated control & 0 & $3 \cdot 47$ & $6 \cdot 89$ & $9 \cdot 97$ & 1.93 & $7 \cdot 65$ & $10 \cdot 56$ & $18 \cdot 11$ & $23 \cdot 10$ & $1 \cdot 62$ & $11 \cdot 65$ \\
\hline M. incognita & 1 & 3.01 & $5 \cdot 40$ & $10 \cdot 86$ & 1.44 & $7 \cdot 85$ & $10 \cdot 62$ & $15 \cdot 85$ & $20 \cdot 82$ & $1 \cdot 25$ & 11.65 \\
\hline M. javanica & 2 & $3 \cdot 26$ & $4 \cdot 45$ & $11 \cdot 81$ & $1 \cdot 46$ & $7 \cdot 59$ & $10 \cdot 65$ & $16 \cdot 36$ & $20 \cdot 99$ & $1 \cdot 27$ & $11 \cdot 50$ \\
\hline G. intraradices (BEG 72) & 3 & $9 \cdot 01$ & $12 \cdot 51$ & $31 \cdot 31$ & $2 \cdot 65$ & $14 \cdot 95$ & $13 \cdot 50$ & $23 \cdot 47$ & $43 \cdot 41$ & $2 \cdot 20$ & $19 \cdot 70$ \\
\hline M. incognita + Gi (BEG 72) & 4 & 8.96 & $9 \cdot 27$ & $31 \cdot 01$ & $2 \cdot 66$ & $15 \cdot 55$ & $13 \cdot 17$ & $16 \cdot 94$ & $42 \cdot 46$ & 1.92 & $19 \cdot 55$ \\
\hline M. javanica + Gi (BEG 72) & 5 & $8 \cdot 19$ & $10 \cdot 57$ & $29 \cdot 21$ & $2 \cdot 71$ & $14 \cdot 25$ & $13 \cdot 77$ & $16 \cdot 96$ & $40 \cdot 24$ & $1 \cdot 90$ & $18 \cdot 90$ \\
\hline G. mosseae (BEG 116) & 6 & $5 \cdot 36$ & $9 \cdot 49$ & $27 \cdot 06$ & $2 \cdot 19$ & $13 \cdot 15$ & $11 \cdot 82$ & $21 \cdot 07$ & $26 \cdot 04$ & $2 \cdot 19$ & $10 \cdot 25$ \\
\hline M. incognita + Gm (BEG 116) & 7 & $5 \cdot 83$ & $7 \cdot 61$ & $27 \cdot 08$ & $2 \cdot 00$ & $13 \cdot 15$ & 11.03 & $16 \cdot 26$ & $24 \cdot 43$ & $1 \cdot 89$ & $12 \cdot 10$ \\
\hline M. javanica + Gm (BEG 116) & 8 & $5 \cdot 25$ & 6.09 & $24 \cdot 83$ & $2 \cdot 23$ & $12 \cdot 30$ & $13 \cdot 16$ & $15 \cdot 63$ & $25 \cdot 02$ & 1.92 & $11 \cdot 79$ \\
\hline \multicolumn{12}{|l|}{ Contrasts $(P)^{\mathrm{c}}$} \\
\hline 0 vs. 3,6 & & $<0.001$ & ns & $<0.001$ & 0.034 & 0.001 & 0.001 & $<0.001$ & $<0.001$ & 0.001 & 0.001 \\
\hline 0 vs. 1,2 & & ns & ns & ns & 0.035 & ns & ns & ns & ns & 0.026 & ns \\
\hline 1 vs. 4,7 & & $<0.001$ & ns & $<0.001$ & $<0.001$ & $<0.001$ & 0.017 & ns & $<0.001$ & $<0.001$ & $<0.001$ \\
\hline 2 vs. 5,8 & & $<0.001$ & ns & $<0.001$ & $<0.001$ & $<0.001$ & $<0.001$ & ns & $<0.001$ & $<0.001$ & $<0.001$ \\
\hline
\end{tabular}

${ }^{2}$ Data are means of 20 replicated olive planting stocks per treatment combination. Plants were inoculated with 15000 eggs $+J_{2}\left(P_{i}\right)$ of Meloidogyne spp. ${ }^{\mathrm{b}}$ Average growth of each parameter during the experiment.

${ }^{c}$ Orthogonal single-degree of freedom contrast of treatments. Probability for the $t$ statistic of linear single-degree of freedom contrasts; ns $=$ not significant $(P>0.05)$. 
caused by soilborne pathogens, through improvement of $\mathrm{P}$ absorption by plants as well as direct competition with the pathogen for infection sites and nutrients, among other mechanisms (Azcón-Aguilar \& Barea, 1996). The effectiveness of AMF in conferring protection against plant-parasitic nematodes has been documented in several pathosystems (Calvet et al., 2001). Therefore the use of AMF to protect planting material against Meloidogyne spp. could be a useful preplanting measure for the integrated management of root-knot nematodes in olive production.

As far as is known, this is the first report on the use of AMF for controlling root-knot nematodes in olive plants. Results of the experiments did not reveal a significant effect of infection by M. incognita race 1 or M. javanica on reduction of the plant fresh weight and shoot height of olive cvs Arbequina and Picual, irrespective of plant age of cv. Arbequina, except for a small reduction in root FW in 4-month-old plants. Nevertheless, the study suggests that main stem diameter is a highly sensitive parameter for assessing damage caused by the two Meloidogyne spp. on both cultivars, and this concurs with previous work (Sasanelli et al., 1997; Nico et al., 2003). Although parasitism by these root-knot nematodes can impair growth of olive plants under controlled conditions, as indicated by Sasanelli et al. (2002) for several olive cvs infected by M. javanica (Sasanelli et al., 2002), it would be advisable to perform long-term experiments under field or microplot conditions to assess further the damaging potential of these nematodes to growth and yield of olive cultivars.

Indigenous mycorrhizae have been found to infect longterm established olive tree plantations naturally, resulting in a substantial promotion of plant fitness (Roldán-Fajardo \& Barea, 1985; Calvente et al., 2004). Artificial inoculation of olive planting stocks with AMF has been adopted by an increasing number of nursery managers as a method for promoting growth, production and precocity, especially in microprogated plants. Recent studies revealed that inoculation of micropropagated cv. Arbequina and Leccino olive planting stocks with selected AMF species improved plant growth and quality of nursery-produced plants, with AMF-isolates G. intraradices (BEG 123) and G. viscosum (BEG 126) being the most effective of the fungi tested (Calvente et al., 2004). Results of the present work confirm that those two AMF species, as well as other isolates of the same species, can significantly improve growth of olive planting stocks irrespective of cultivar, age and infection by the root-knot nematodes $M$. incognita race 1 and $M$. javanica. Colonization of olive roots by AMF was generally high in both experiments; however, in each experiment the percentage root colonization by AMF was modified by nematode infection, depending on the AMF isolate-olive planting stock combination. The main causes affecting the arbuscular phase and production of storage structures (vesicles and internal spores) appear to be a reduction of spaces for fungal colonization (Smith, 1988) and a decrease in the supply of carbohydrates in the roots (Wallace, 1987), as a result of nematode migration and feeding with formation of giant cells in the cortical parenchyma, endodermis, pericycle and vascular parenchyma of olive root tissues (Nico et al., 2002).

Root infections by $M$. incognita race 1 and M. javanica resulted in moderate root galling and reproduction rates of the nematodes in both olive cultivars. These results agree with previous observations in naturally and artificially nematode-infected planting stocks of cultivars in nurseries in Andalusia (Nico et al., 2002, 2003), and are similar to those reported by Sasanelli et al. (1997) in artificially inoculated plants. In the experiments, described here, mycorrhizal infection improved growth of olive planting stocks for all parameters tested, irrespective of cultivar or plant age, and this improved growth appeared to confer tolerance against parasitism by M. incognita race 1 and M. javanica. Severity of root galling, as well as the reproduction rate of the two nematode species, were significantly reduced in mycorrhizal plants compared with nonmycorrhizal ones. The lower root galling severity and nematode reproduction rate in the roots of plants colonized by AMF clearly indicates a suppressive effect of AMF to parasitism by root-knot nematodes in olive planting stocks. These results agree with previous reports on the suppression of root-knot nematode populations by mycorrhizal fungi, such as M. javanica in a peach orchard in southern Spain (Calvet et al., 2001), and M. incognita in banana plants ( Jaizme-Vega et al., 1997). Other studies, however, showed that populations of root-knot nematodes in specific nematode-host associations were unaffected by AMF (M. incognita-cotton, Smith et al., 1986; M. incognita-tamarillo, Thomson Cason et al., 1983; M. javanica-micropropagated banana, Pinochet et al., 1997), suggesting that both root-knot nematodes and AMF may co-infect without interactions. Nevertheless, AMF can interact with other microorganisms in the rhizosphere ( Jeffries et al., 2003). In this context, formation of AMF may change plant physiology and certain nutritional and physical properties of the rhizoplane and/or rhizosphere, affecting the patterns of microbial colonization (Gryndler, 2000). Although the mechanism(s) that enabled the beneficial effects of mycorrhiza against root-knot nematode attack remain unknown, improved nutrient status, competition for nutrients and penetration sites, anatomical or physiological changes in roots, microbial changes in the rhizosphere and activation of plant defence mechanisms may be important factors (Hussey \& Roncadori, 1982).

In summary, the results reported here indicate that early inoculation of planting stocks of olive cvs Arbequina and Picual with G. intraradices, G. mosseae or G. viscosum favour plant growth and confer protection against the root-knot nematodes $M$. incognita race 1 and $M$. javanica by inhibiting nematode reproduction, reducing the severity of root galling and, probably, by enhancing olive plant nutrition, as reported previously in pear rootstocks (López et al., 1997). Thus the use of mycorrhizal planting material during olive plant propagation in nurseries may be a useful practice for minimizing the effects of root-knot nematode infections in olive planting stocks, and to protect these plants against later infections in commercial olive orchards. 


\section{Acknowledgements}

Research was supported in part by grant CAO-99-010C3-01, -02, -03 from Instituto Nacional de Investigación y Tecnología Agraria y Alimentaria (INIA) of Spain. The authors thank J. Martín-Barbarroja, IAS-CSIC for technical assistance; R. Calvente, EEZ-CSIC for her valuable help with mycorrhizal inocula; and B.B. Landa, J.A. NavasCortés for critical review of the manuscript.

\section{References}

Atilano RA, Menge JA, Van Gundy SD, 1981. Interaction between Meloidogyne arenaria and Glomus fasciculatus in grape. Journal of Nematology 13, 52-7.

Azcón-Aguilar C, Barea JM, 1996. Arbuscular mycorrhizas and biological control of soil-borne plant pathogens - an overview of the mechanisms involved. Mycorrhiza 6, 457-64.

Barea JM, Azcón R, Azcón-Aguilar C, 2002. Mycorrhizosphere interactions to improve plant fitness and soil quality. Antonie Van Leeuwenhoek 81, 343-51.

Barranco D, 2004. Variedades y patrones. In: Barranco D, Fernández-Escobar R, Rallo L, eds. El Cultivo del Olivo. Madrid, Spain, Junta de Andalucía and Ediciones Mundi-Prensa, 63-91.

Caballero JM, del Río C, 2004. Métodos de multiplicación. In: Barranco D, Fernández-Escobar R, Rallo L, eds. El Cultivo del Olivo. Madrid, Spain, Junta de Andalucía and Ediciones Mundi-Prensa, 91-123.

Calvente R, Cano C, Ferrol N, Azcon-Aguilar C, Barea JM, 2004. Analysing natural diversity of arbuscular mycorrhizal fungi in olive tree (Olea europaea L.) plantations and assessment of the effectiveness of native fungal isolates as inoculants for commercial cultivars of olive plantlets. Applied Soil Ecology 26, 11-9.

Calvet C, Pinochet J, Hernández Dorrego A, Estaún V, Camprubí A, 2001. Field microplot performance of the peach-almond hybrid GF-677 after inoculation with arbuscular mycorrhizal fungi in a replant soil infested with root-knot nematodes. Mycorrhiza 10, 295-300.

Carling DE, Roncadori RW, Hussey RS, 1989. Interactions of vesicular-arbuscular mycorrhizal fungi, root-knot nematode, and phosphorus fertilization on soybean. Plant Disease 73, 730-3.

Carling DE, Roncadori RW, Hussey RS, 1996. Interactions of arbuscular mycorrhizae, Meloidogyne arenaria, and phosphorus fertilization on peanut. Mycorrhiza 6, 9-13.

Coolen WA, 1979. Methods for the extraction of Meloidogyne spp. and other nematodes from roots and soil. In: Lamberti F, Taylor CE, eds. Root-Knot Nematodes (Meloidogyne species) Systematics, Biology and Control. London, UK: Academic Press, 317-29.

Cooper KM, Grandison GS, 1986. Interaction of vesiculararbuscular mycorrhizal fungi and root-knot nematode on cultivars of tomato and white clover susceptible to Meloidogyne hapla. Annals of Applied Biology 108, 555-66.

Estaún V, Camprubí A, Calvet C, Pinochet J, 2003. Nursery and field response of olive trees inoculated with two arbuscular mycorrhizal fungi, Glomus intraradices and Glomus mosseae. Journal of the American Society of Horticultural Sciences 128, 767-75.
FAO, 2004. Faostat Statistical Databases. http://apps.fao.org/ page/collections [accessed 29 January 2006].

Giovannetti M, Mosse B, 1980. An evaluation of techniques for measuring VAM infection in roots. New Phytologist 84, 489-500.

Gomez KA, Gomez AA, 1984. Statistical Procedures for Agricultural Research. New York, USA: John Wiley.

Gryndler M, 2000. Interactions of arbuscular mycorrhizal fungi with other soil organisms. In: Kapulnik Y, Douds DD Jr, eds. Arbuscular Mycorrhizas: Physiology and Function. Dordrecht, the Netherlands: Kluwer Academic, 239-62.

Hoagland DR, Arnon DI, 1950. The Water Culture Method for Growing Plants without Soil. Circular no. 347. California Agriculture Experiment Station, University of California.

Hussey RS, Barker KR, 1973. A comparison of methods of collecting inocula of Meloidogyne spp., including a new technique. Plant Disease Reporter 57, 1025-8.

Hussey RS, Roncadori RW, 1982. Vesicular-arbuscular mycorrhizae may limit nematode activity and improve plant growth. Plant Disease 66, 9-14.

Jaizme-Vega MC, Tenoury P, Pinochet J, Jaumot M, 1997. Interactions between the root-knot nematode Meloidogyne incognita and Glomus mosseae in banana. Plant and Soil 196, 27-35.

Jeffries P, Gianinazzi S, Perotto S, Turnau K, Barea JM, 2003. The contribution of arbuscular mycorrhizal fungi in sustainable maintenance of plant health and soil fertility. Biology and Fertility of Soils 37, 1-16.

Koske RE, Gemma JH, 1989. A modified procedure for staining roots to detect VA mycorrhizas. Mycological Research 92, 86-95.

Lamberti F, Baines RC, 1969. Pathogenicity of four species of Meloidogyne on three varieties of olive trees. Journal of Nematology 1, 111-5.

López A, Pinochet J, Fernández C, Calvet C, Camprubí A, 1997. Growth response of OHF-333 pear rootstock to arbuscular mycorrhizal fungi, phosphorus nutrition and Pratylenchus vulnus infection. Fundamental and Applied Nematolology 20, 87-93.

MacGuidwin AE, Bird GW, Safir GR, 1985. Influence of Glomus fasciculatum on Meloidogyne hapla infecting Allium cepa. Journal of Nematology 17, 389-95.

Marull J, Pinochet J, 1991. Host suitability of Prunus rootstocks to four Meloidogyne species and Pratylenchus vulnus in Spain. Nematropica 21, 185-95.

Nico AI, Rapoport HF, Jiménez-Díaz RM, Castillo P, 2002. Incidence and population density of plant-parasitic nematodes associated with olive planting stocks at nurseries in southern Spain. Plant Disease 86, 1075-9.

Nico AI, Jiménez-Díaz RM, Castillo P, 2003. Host suitability of the olive cultivars Arbequina and Picual for plant-parasitic nematodes. Journal of Nematology 35, 29-34.

Phillips JM, Hayman DS, 1970. Improved procedures for clearing roots and staining parasitic and vesicular-arbuscular mycorrhizal fungi in soil. Transactions of the British Mycological Society 55, 158-61.

Pinochet J, Fernández C, Jaizme MC, Tenoury P, 1997. Micropropagated banana infected with Meloidogyne javanica responds to Glomus intraradices and phosphorus. Hortscience 32, 101-3.

Rinaldelli E, Mancuso S, 1996. Response of young mycorrhized 
and non-mycorrhized plants of olive tree (Olea europaea L.) to saline conditions. I. Short-term electrophysiological and long-term vegetative salt effects. Advances of Horticultural Sciences 10, 126-90.

Roldán-Fajardo BE, Barea JM, 1985. Mycorrhizal dependency in the olive tree (Olea europaea L.). In: Gianinazzi-Pearson V, Gianinazzi S, eds. Physiological and Genetical Aspects of Mycorrhizae. Paris, France: INRA, 323-6.

Ruiz-Lozano JM, 2003. Arbuscular mycorrhizal symbiosis and alleviation of osmotic stress. New perspectives for molecular studies. Mycorrhiza 13, 309-17.

Sasanelli N, D'Addabbo T, Moura Lemos R, 2002. Influence of Meloidogyne javanica on growth of olive cuttings in pots. Nematropica 32, 59-63.

Sasanelli N, Fontanazza G, Lamberti F, D’Addabbo T, Patumi M, Vergari G, 1997. Reaction of olive cultivars to Meloidogyne species. Nematologia Mediterranea 25, 183-90.

Sasser JN, Freckman DW, 1987. A world perspective on nematology: the role of the society. In: Veech JA,
Dickson DW, eds. Vistas on Nematology. Hyattsville, MD, USA: Society of Nematologists, 7-14.

Sieverding E, 1991. Vesicular-Arbuscular Mycorrhiza Management in Tropical Agrosystems. Eschborn, Germany: GTZ.

Smith GS, 1988. The role of phosphorus nutrition in the interactions of vesicular-mycorrhizal fungi with soilborne nematodes and fungi. Phytopathology 78, 371-4.

Smith GS, Hussey RS, Roncadori RW, 1986. Penetration and postinfection development of Meloidogyne incognita on cotton as affected by Glomus intraradices and phosphorus. Journal of Nematology 18, 429-35.

Thomson Cason KM, Hussey RS, Roncadori RW, 1983. Interaction of vesicular-arbuscular mycorrhizal fungi and phosphorus with Meloidogyne incognita on tomato. Journal of Nematology 15, 410-7.

Wallace HR, 1987. Effects of nematode parasites on photosynthesis. In: Veech JA, Dickson DW, eds. Vistas on Nematology. Hyattsville, MD, USA: Society of Nematologists, 253-9. 